\title{
ASSESSMENT OF TOXIC ELEMENTS CONTAMINATION IN SURFACE WATER AND SEDIMENTS IN A MINING AFFECTED AREA
}

\author{
ANA MOLDOVAN ${ }^{a, b}$, ANAMARIA IULIA TÖRÖK ${ }^{a *}$, OANA CADAR ${ }^{a}$, \\ MARIUS ROMANa, CECILIA ROMAN ${ }^{\mathrm{a}}$, VALER MICLE ${ }^{\mathrm{b}}$
}

\begin{abstract}
To assess the spatial and temporal contamination with toxic elements (As, $\mathrm{Cd}, \mathrm{Cr}, \mathrm{Cu}, \mathrm{Pb}, \mathrm{Ni}, \mathrm{Zn}$ ), surface water and sediments were collected in 2019 and 2020, from Valea Sesii, a contaminated water stream in Romania. The toxic metal contamination of water was assessed using heavy metals evaluation index ( $\mathrm{HEl})$, heavy metals pollution index (HPI) and of sediments using contamination factor $\left(\mathrm{C}_{f}\right)$ and geo-accumulation index (Igeo). The metal concentrations were comparable within the two years, suggesting that the natural attenuation process was inadequate, and treatment technologies are required to improve surface water and sediment quality. The surface water presented high degree of metal contamination in 2019 as indicated by $\mathrm{HPI}>100$ and $\mathrm{HEI}<10$. The toxic metal concentrations in sediments were very high for $\mathrm{Cd}, \mathrm{Ni}, \mathrm{Pb}$ and $\mathrm{Cu}$, with highest Igeo value for $\mathrm{Cd}$ and $\mathrm{C}_{\mathrm{f}}$ for $\mathrm{Ni}$. Surface water and sediments showed signs of high level of contamination in the sampling points located downstream of the copper mine discharge point, an improvement of their quality being noticed with distancing from the mining discharge area. This study is a first step for a comprehensive risk assessment and for an integrated environmental management.
\end{abstract}

Keywords: metal contamination, river water, sediments, HEl, HPI, contamination index, Igeo

\section{INTRODUCTION}

Contamination of surface water due to the wastewater discharge is of major concern, as reported by several previous studies [1-4]. Human activities have an important impact on the environment, including changes in biophysical

\footnotetext{
a INCDO-INOE 2000, Research Institute for Analytical Instrumentation, 67 Donath Street, 400293 Cluj-Napoca, Romania

b Technical University, Faculty of Materials and Environmental Engineering, 103-105 Muncii Boulevard, 400641 Cluj-Napoca, Romania

* Corresponding author: iulia.torok@icia.ro
} 
environments, in ecosystems, biodiversity and natural resources, alterations that interfere with the natural processes [5]. In freshwater ecosystems, the metal contamination may result from precipitation, geologic weathering or through the discharge of agricultural, municipal, domestic or industrial waste products $[6,7]$. Due to industrialization processes and anthropogenic activities (especially mining, ore processing) conducted in the area, a large number of pollutants were discharged into the surface water, deteriorating the river water quality. Moreover, the hydrology of the river is an important factor in the accumulation and transformation of metals. Also, the river water quality is affected by natural processes such as precipitation and weathering [8].

Contamination in the aquatic systems raises high concerns due to the potential toxicity of metals and their harmful effects on the biota $[9,10]$. Heavy metals from natural minerals are more stable, while heavy metals from anthropogenic sources tend to be more mobile and bioavailable, representing greater health and environmental risks [11, 12]. With their long persistence, bioaccumulation, and bio-magnification character, heavy metals from freshwater ecosystems are ultimately adsorbed into the sediments [13] and may bioaccumulate, causing toxic effects at points far from the contamination source [14]. Rivers can act as secondary sources of heavy metals for the adjacent marine environment, being their dominant transport pathway from the source to the environment [15-17]. Therefore, periodic monitoring of the heavy metal concentrations and their spatial distribution in the studied environmental media is required.

The determination of heavy metals concentration in water and sediment is a critical step in defining the level of contamination in the aquatic ecosystems and their potential impact on the environment [18-20]. Thus, environmental quality indicators and pollution indices have been developed for processing and analysing the anthropic inputs and their influence on the environmental quality status $[21,22]$.

The mining industry is an important waste producer worldwide, with a high influence on environmental quality [23]. Due to the formation of sulphide oxidation, sulphidic mine tailing (pyrite, jarosite, sphalerite, galena) favours metal mobility from mining waste to streams. Minerals with a strong acid reduction potential are an effective waste stabilization strategy for minimizing the sulphide potential of metals dissolving and neutralizing acidic waters. Also, the use of non-reactive materials in the construction of tailing impoundments, compacting the material in order to limit water and oxygen flow and increase stability, and complete water saturation of the impoundment in order to prevent oxidation in the beach area are measures that could reduce the risk of surface water and sediments contamination from mining activities [24-26].

Earlier studies assessed the water quality and contamination risk in catchments near mining areas and their vicinity [24, 25, 27, 28]. Ozunu et al. [24] studied the quality of surface waters in the Aries River, near a mining 
area, and their results revealed that the waters discharged by mining tailings considerably impact the environment. The surface water quality from the Aries catchment was also investigated by Levei et al. [27] and increased Mn, $\mathrm{Cu}, \mathrm{Fe}, \mathrm{Pb}$ and sulphates concentrations were found, whereas other metals were only slightly increased. However, to the best of our knowledge, the relationship between the water and sediment quality has been less studied. In this context, the novelty of the present study lies in the integration of individual and synergistic assessment of toxic metals in sediment and water, as well as in the determination of the influence of water contamination on sediment sample quality.

An exhaustive evaluation of spatial and temporal trends of toxic metal contamination in the Valea Sesii rivulet from 2019 and 2020 is presented in this study. Beside the metal concentrations in the surface water and sediment, heavy metal pollution index $(\mathrm{HPI})$, heavy metal evaluation index $(\mathrm{HEI})$, geoaccumulation index (Igeo), contamination factor $\left(C_{f}\right)$ and degree of contamination $\left(C_{d}\right)$ were also used in the assessment of the contamination level of water and sediment samples. The combination of the individual $\left(I_{g e o}\right.$ and $\left.C_{f}\right)$ and synergistic $\left(\mathrm{C}_{\mathrm{d}}, \mathrm{HPI}, \mathrm{HEl}\right)$ assessments of the seven toxic metals (As, Cd, $\mathrm{Cr}, \mathrm{Cu}, \mathrm{Pb}, \mathrm{Ni}, \mathrm{Zn}$ ) will provide a more comprehensive view on the toxic metal contamination status in the Valea Sesii rivulet. The obtained results will provide a background for future ecological and human health risk assessments and for the development of curatives measures for the river's surface water and sediment quality. In addition, this research can offer the necessary information support for a more comprehensive toxic metal contamination assessment in all the mining affected rivers in the world.

\section{RESULTS AND DISCUSSION}

The surface water and sediment were sampled from six different locations among the Valea Sesii rivulet catchment (Fig. 1) in two different years: 2019 and 2020.

\section{Toxic metal concentration in surface water}

All the studied metals were detected at a level above the method quantification limits in the surface water samples over a two-year sampling campaign (2019-2020) set for six sampling locations (L1-L6), as shown in Fig. 1. Zn, Cu and Ni were the dominant elements in all the locations and years.

Regarding the spatial variation, the metal concentrations from the selected locations were compared. The L1 and L2 results did not differ from each other, having the lowest concentrations of metals among the studied waters, indicating that no anthropogenic interference influenced the water 
chemistry. On the other hand, all metals had their highest concentrations in L3, indicating that the contamination source could be situated between L2 and L3. L3 was located downstream of the discharge point of the Rosia Poieni tailing impoundment. Downstream $L 3$, the samples also had relatively high concentration of metals, the only influence among their content's variation seemed to be due to the dilution phenomenon.

Comparing the metal concentrations between 2019 and 2020, most of the metal concentrations (except for $\mathrm{Cr}, \mathrm{Pb}$ and $\mathrm{Zn}$ ) reached their highest values in 2020.

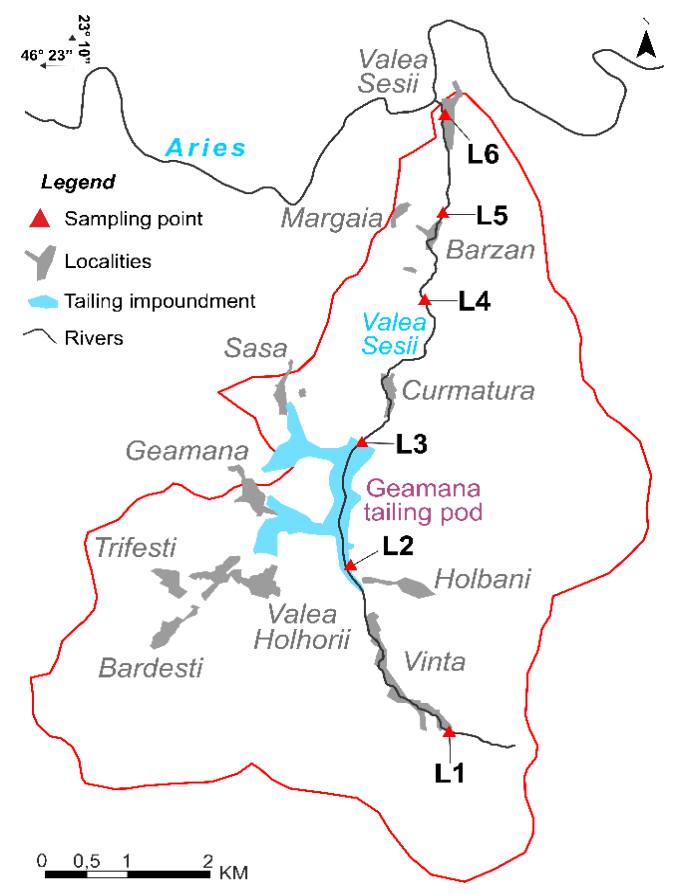

Figure 1. Map of the sampling points in Valea Sesii area

$\mathrm{Cu}$ and $\mathrm{Zn}$ concentrations had exceeded the quality standards imputed for the $\mathrm{V}$ class of surface water quality by the Romanian and European legislation (Minister's Order 161/2006/OD and Directive 2008/32/CE), in four out of the six sampling sites $[29,30]$. Downstream $L 3$, Cu concentration ranged between 115 and $159 \mu \mathrm{g} / \mathrm{L}$ in 2019 and between 142 and $214 \mu \mathrm{g} / \mathrm{L}$ in 2020, respectively. In the case of $\mathrm{Zn}$, the concentration ranged from 1813 to $1247 \mu \mathrm{g} / \mathrm{L}$ in 2019, and between 2001 and $1422 \mu \mathrm{g} / \mathrm{L}$ in 2020 . The mean value of $\mathrm{Ni}$ over the two-year sampling campaigns had a value of $120 \mu \mathrm{g} / \mathrm{L}$ and a standard deviation of $82.5 \mu \mathrm{g} / \mathrm{L}$. With a mean concentration of $45.7 \mu \mathrm{g} / \mathrm{L}$ and a standard 
deviation of $33.8 \mu \mathrm{g} / \mathrm{L}$, As had its highest value in the water sample from L3 $(103 \mu \mathrm{g} / \mathrm{L})$ in $2020,2.5$ times higher than the quality standards established by legislation limit values for the $V$ class of surface water quality $[29,30]$. The water in $\mathrm{L} 3$ had poor quality due to the high $\mathrm{Cd}, \mathrm{Cr}$, and $\mathrm{Pb}$ concentration, with mean concentration values of $1.29 \mu \mathrm{g} / \mathrm{L}$ for $\mathrm{Cd}, 107 \mu \mathrm{g} / \mathrm{L}$ for $\mathrm{Cr}$, respectively $23.5 \mu \mathrm{g} / \mathrm{L}$ for $\mathrm{Pb}$ [30].

a)
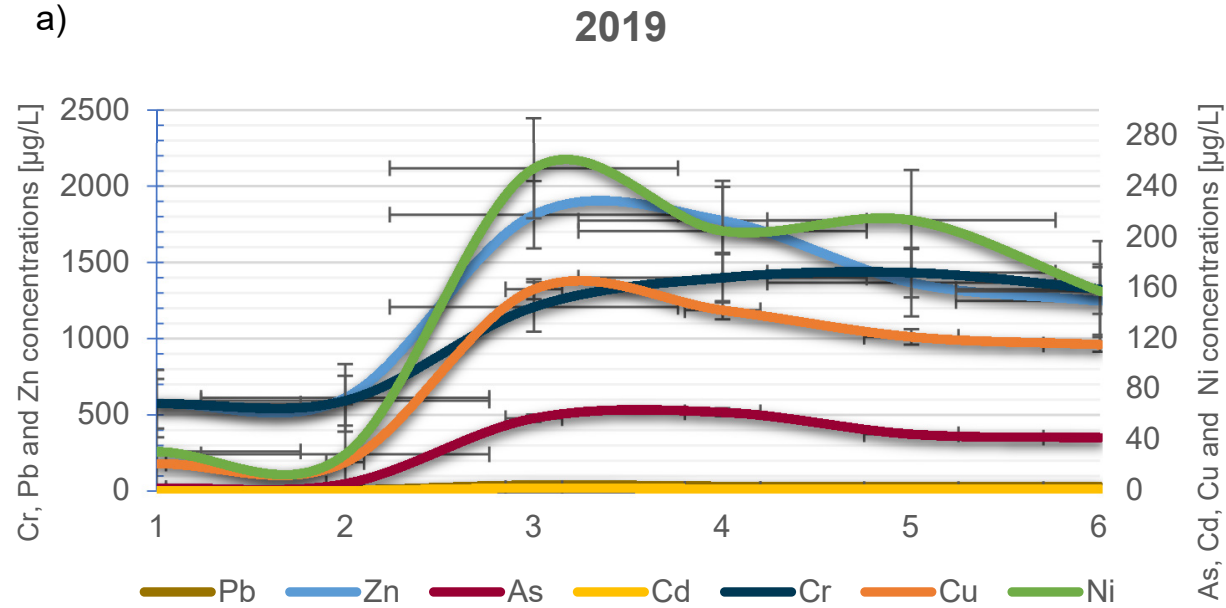

Sampling sites

b) 2020

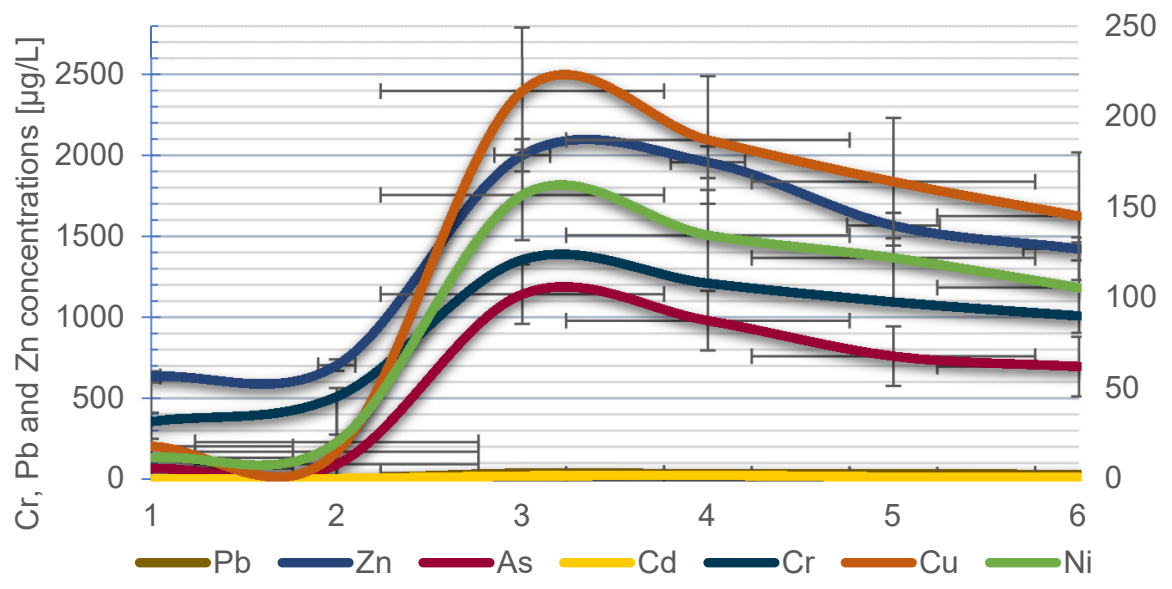

Figure 2. The spatial and temporal variation (a) 2019; b) 2020) of metal concentrations in the Valea Sesii rivulet water samples 
The metal concentration trend varied over the two-year duration. This may be due to accidental discharges, annual precipitation, or change in production activities. Thus, an overall conclusion of the toxic metal concentration variation trend was difficult to draw.

The obtained results indicated that $\mathrm{Cu}, \mathrm{Ni}$ and $\mathrm{Zn}$ concentrations were higher than the class $V$ of the national surface water quality standards in the case of $\mathrm{L} 3$, L4, L5 and L6, while for $\mathrm{Cr}$ and $\mathrm{Pb}$, the metal concentrations were higher than the class III of the national surface water quality standards [30]. Due to $\mathrm{Zn}$ and Ni concentrations, L1 and L2 were included in the class II of the national surface water quality standards [30]. As expected, the concentrations of metals decreased as the distance from sources of contamination increased along the flow direction.

A similar study done by Levei et al. (2011) for Aries River catchment has showed that the levels of $\mathrm{Ni}, \mathrm{Cu}, \mathrm{Cd}$ and $\mathrm{Zn}$ in Vales Sesii rivulet had exceeded the quality standards established by legislation limit values for the $V$ class of surface water quality $[29,30]$. Moreover, our findings were in accordance to Senila results regarding the $\mathrm{Cu}$ and $\mathrm{Zn}$ concentrations [31]. Similar results were reported by Ning [32] for a water stream near a gold mine area in China, where the metal concentrations were higher than the III or IV class of the national surface water quality standards, indicating, in general, an average quality of the surface water in the study area.

\section{Metal concentration in sediment samples}

The metal concentrations in sediment samples are presented in Table 1. In general, the metal contents in sediment are higher than in surface water because of their ability to precipitate, accumulate, and bind strongly to sediments [33].

Regarding the spatial variations among sampling sites, the highest metal concentration was measured in the case of $L 3$ and $L 4$, while the lowest in L1 and L2, similar to the metal concentration in the surface water samples, as shown in Fig. 2.

Compared with the samples from 2019, the toxic metal concentrations in sediment presented some variations. While the $\mathrm{Cr}$ concentration was notably higher in all the sediment samples, the $\mathrm{Zn}$ and $\mathrm{Ni}$ concentrations were lower in the case of L3, L4, L5 and L6. Even so, the sediment samples had similar concentration, implying that the sediment quality did not improve over two years. Therefore, the natural attenuation process of the river was proven to be inadequate or insufficient. In order to improve the quality of the river, it is recommended to implement some remediation actions (e.g., employing sediment clean-up operations and enforcing stringent discharge standards). 
ASSESSMENT OF TOXIC ELEMENTS CONTAMINATION IN SURFACE WATER AND SEDIMENTS IN A MINING AFFECTED AREA

Table 1. The metal content identified in the sediment samples in $\mathrm{mg} / \mathrm{kg}$

\begin{tabular}{|c|r|r|c|c|c|c|c|c|c|c|c|c|c|c|}
\hline & \multicolumn{9}{|c|}{$\mathbf{2 0 1 9}$} & \multicolumn{8}{|c|}{$\mathbf{2 0 2 0}$} \\
\hline & \multicolumn{1}{|c|}{ As } & \multicolumn{1}{c|}{ Cd } & $\mathbf{C r}$ & $\mathbf{C u}$ & $\mathbf{~ P b}$ & $\mathbf{~ N i}$ & $\mathbf{Z n}$ & $\mathbf{A s}$ & $\mathbf{C d}$ & $\mathbf{C r}$ & $\mathbf{C u}$ & $\mathbf{P b}$ & $\mathbf{~ N i}$ & $\mathbf{Z n}$ \\
\hline L1 & 2.84 & 0.040 & 16.8 & 6.18 & 12.10 & 6.20 & 6.88 & 4.12 & 0.032 & 22.7 & 8.12 & 10.7 & 12.4 & 7.18 \\
\hline L2 & 3.84 & 0.054 & 14.5 & 4.22 & 14.30 & 7.22 & 10.4 & 4.05 & 0.048 & 27.3 & 7.55 & 9.45 & 15.6 & 7.40 \\
\hline L3 & 22.70 & 1.12 & 97.8 & 88.3 & 66.8 & 233 & 46.1 & 19.0 & 0.812 & 86.0 & 72.4 & 72.1 & 277 & 40.8 \\
\hline L4 & 18.90 & 0.975 & 66.3 & 86.8 & 75.8 & 286 & 52.8 & 27.3 & 0.745 & 96.3 & 87.4 & 76.4 & 218 & 37.8 \\
\hline L5 & 17.40 & 0.827 & 54.1 & 67.8 & 54.3 & 218 & 44.3 & 16.8 & 0.541 & 60.8 & 66.8 & 60.3 & 187 & 32.4 \\
\hline L6 & 12.00 & 0.642 & 60.8 & 53.8 & 50.7 & 177 & 38.7 & 12.2 & 0.42 & 52.7 & 48.5 & 52.4 & 166 & 34.2 \\
\hline Average & 12.9 & 0.610 & 51.7 & 51.2 & 45.7 & 155 & 33.20 & 9.04 & 0.335 & 30.0 & 33.8 & 29.8 & 109 & 15.3 \\
\hline SDTV & 8.20 & 0.46 & 31.7 & 37.8 & 26.7 & 120 & 19.58 & 4.05 & 0.032 & 22.7 & 7.55 & 9.45 & 12.4 & 7.18 \\
\hline Min & 2.84 & 0.04 & 14.5 & 4.22 & 12.1 & 6.20 & 6.88 & 27.3 & 0.812 & 96.3 & 87.4 & 76.4 & 277 & 40.8 \\
\hline Max & 22.7 & 1.12 & 97.8 & 88.3 & 75.8 & 286 & 52.8 & 13.9 & 0.432 & 57.7 & 48.5 & 46.9 & 146 & 26.6 \\
\hline
\end{tabular}

$\mathrm{Ni}, \mathrm{Zn}, \mathrm{Cu}$ and $\mathrm{Cd}$ had the highest concentration among the studied metals. Downstream L3, Ni and Cu concentrations were 1.2 - 2 times higher than the upper value of the sediment quality guideline established by the Romanian legislation [30]. $\mathrm{Zn}$ and $\mathrm{Cd}$ had their highest concentration in the sediment samples from L4 and L3, with slightly higher concentration than the sediment guideline for those specific toxic metals, $52.8 \mathrm{mg} / \mathrm{kg}$ dry wt. in the case of Zn (L4), respectively $1.12 \mathrm{mg} / \mathrm{kg}$ dry wt. in the case of Cd (L3). As, $\mathrm{Cr}$ and $\mathrm{Pb}$ concentrations were lower than the upper limit of those standards.

\section{Assessment of toxic metal contamination trends using pollution indices}

The HPI and HEI were used to assess the surface water's level of contamination with heavy metals, which were calculated using the Romanian and European legislation [29, 30] and the concentration level of $\mathrm{Cd}, \mathrm{Cr}, \mathrm{Cu}$, $\mathrm{Pb}, \mathrm{Ni}$ and $\mathrm{Zn}$ from the analyzed water samples.

The value of HPI ranged from 18.3 to 145 , with an average value of 84.6 in 2019, and from 12.4 to 103, with an average value of 62.4 in 2020 . In 2019 , for four out of six samples, the HPI exceeded the critical value of 100 , indicating a high level of heavy metal contamination. As shown in Fig. 3a, the spatial trends of $\mathrm{HPI}$ varied as follows: $\mathrm{L} 3>\mathrm{L} 4>\mathrm{L} 5>\mathrm{L} 6>\mathrm{L} 1>\mathrm{L} 2$. $\mathrm{L} 3$ had the highest HPI value of 145 in 2019 and 103 in 2020, indicating that the site was highly contaminated with heavy metals, while L2 had the lowest HPI (18.3 in 2019 and 12.4 in 2020), presenting moderately contaminated level of heavy metals. 


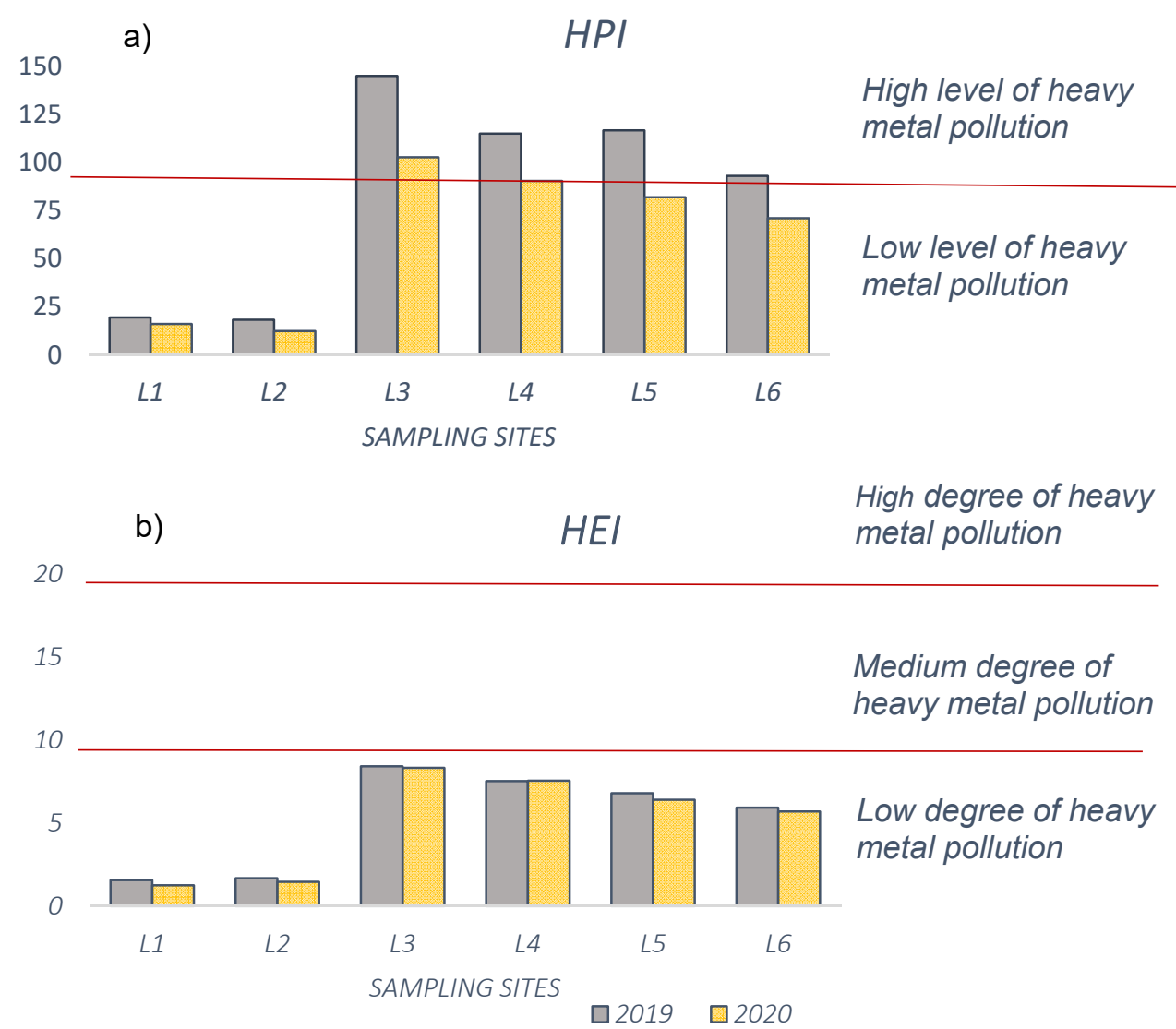

Figure 3. The spatial and temporal variation of heavy metal pollution index $\mathrm{HPI}(\mathrm{a})$ and heavy metal evaluation index HEI (b) in the Valea Sesii rivulet

The geo-accumulation index $\left(\mathrm{I}_{\mathrm{geo}}\right)$ and the contamination factor $\left(\mathrm{C}_{\mathrm{f}}\right)$ were employed for the quantitative measurement of each metal pollution level in the sediment samples. Unlike monitoring data, the individual indices take into consideration the background levels of the heavy metals according to Turekian and Barbieri $[34,35]$, in the case of $I_{g e o}$, or the maximum allowable heavy metal concentration, in the case of $\mathrm{C}_{\mathrm{d}}$. Fig. 4 shows the $\mathrm{I}_{\text {geo }}$ values of the heavy metals at different sampling locations.

Most of the heavy metals had their highest $I_{\text {geo }}$ at L3 and L4, meanwhile, L1 and L2 had uncontaminated levels of every tested metal, with $I_{\text {geo }}$ values lower than 0 . 
a)

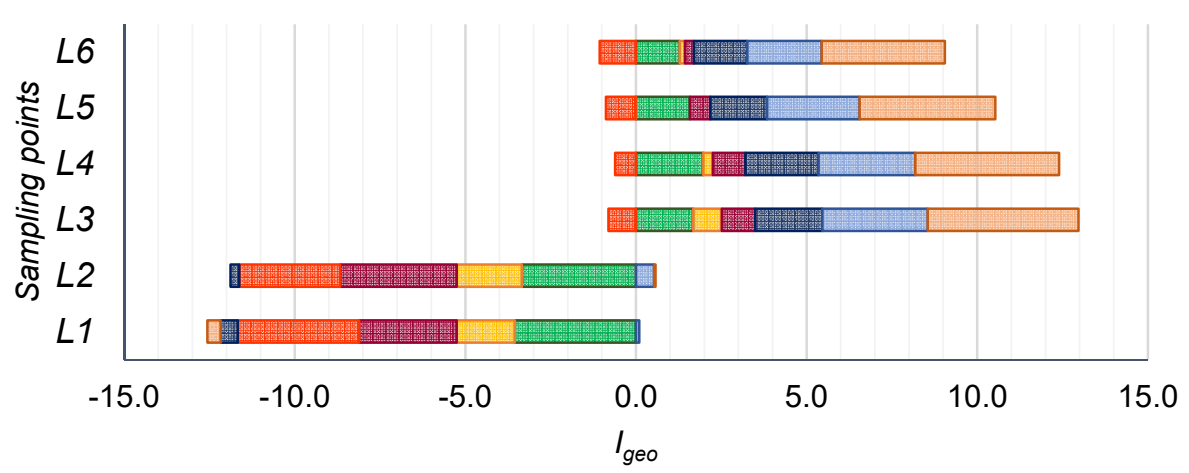

$\square \mathrm{Ni} \square \mathrm{Cr} \quad \mathrm{m} \mathrm{Cu} \square \mathrm{Zn} \quad \mathrm{Pb} \square \mathrm{As} \square \mathrm{Cd}$

b)

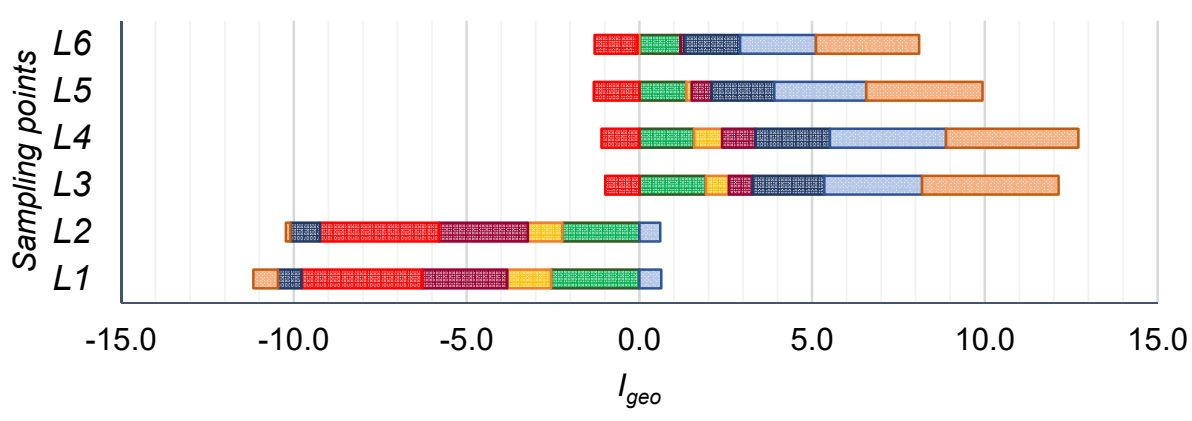

$\square \mathrm{Ni} \square \mathrm{Cr}$ 田 $\mathrm{Cu} \quad \mathrm{Zn}$ 田 $\mathrm{Pb} \square \mathrm{As} \square \mathrm{Cd}$

Figure 4. The geo-accumulation index in the Valea Sesii rivulet sediments in 2019 (a) and 2020 (b)

The sediment samples from L3, L4, L5 and L6 were proven to be highly contaminated with As, L3, L5 and L6 moderately to highly contaminated with $\mathrm{Pb}$, L4 heavily contaminated with $\mathrm{Pb}$. In the case of $\mathrm{Cd}$, I geo varied from -0.395 to 4.41 in $2019,-0.714$ to 3.95 , in 2020 , respectively. A heavily to extremely contaminated level with $\mathrm{Cd}$ for sediments sample from L3 and L4 and a highly contaminated level for sediment sample from L5 and L6 were assigned, while $\mathrm{I}_{\text {geo }}$ for L1 and L2 was lower than 0, suggesting a low contamination level for $\mathrm{Cd}$. 
Regarding the temporal distributions, in 2019, the highest cumulative $I_{\text {geo }}$ value was attributed to L3, while in 2020 , to L4.

The highest $\mathrm{C}_{\mathrm{f}}$ was in the case of $\mathrm{Ni}$, where a very high degree of contamination was attributed to $\mathrm{L} 3$ and $\mathrm{L} 4$, and a considerable degree of $\mathrm{Ni}$ contamination was allocated to L5 and L6. A moderate degree of contamination with $\mathrm{Cu}$ and $\mathrm{Cd}$ was assigned to L3, L4 and L5 in 2019, while in 2020 , the $C_{f}$ of $C d$ was lower, in the case of L4 and L5.

The conclusions about the metal content trends of $I_{\text {geo }}$ values are not very similar compared with the heavy metal content trends assessments based on the $C_{f}$ values. However, both indices suggested high level of toxic metal contamination on sediment, so strategies and technologies to improve sediment quality, such as washing, thermal extraction or bioremediation are necessary and urgent.

The $C_{d}$ index was employed to assess the synergistic contamination of the seven studied heavy metals in the sediment. The average $C_{d}$ value of the six locations in two years was 7.94, indicating that, globally, the sediment samples of the Valea Sesii rivulet were moderately to highly contaminated.

The spatial trends varied in the following order: $\mathrm{L} 4>\mathrm{L} 3>\mathrm{L} 5>\mathrm{L} 6>$ $\mathrm{L} 2>\mathrm{L} 1$ in 2019 and $\mathrm{L} 3>\mathrm{L} 4>\mathrm{L} 5>\mathrm{L} 6>\mathrm{L} 2>\mathrm{L} 1$ in 2020 , respectively. $\mathrm{L} 4$ had the highest $C_{d}$ value of 14.1 and $L 3,13.4$, indicating that the investigated sites were highly contaminated with heavy metals, while $\mathrm{L} 1$ had the lowest $\mathrm{C}_{\mathrm{d}}$ of 0.84 .

There are several mitigation measures to reduce the impact of mining activities, among which environmental monitoring; management and remediation schemes depending on the nature of mine; novel biotechnological methods; precipitation and adsorption processes that reduce the transport of contaminants produced by mining with an emphasis on hyporheic zones; the colmation process, which inhibits the flow of mining pollutants; microbiological processes immobilizing metals (manganese and iron); sulphidic mine tailings remediation by soil and water covers which limit the oxidation rate of the tailing; point source remediation [36-39].

\section{CONCLUSIONS}

The monitoring data, $\mathrm{HEI}, \mathrm{HPI}, \mathrm{C}_{\mathrm{f}}$, and $\mathrm{I}_{\text {geo }}$ indices were used to evaluate toxic metal contamination in the surface water, respectively, in the sediment of the Valea Sesii rivulet, located in an area strongly affected by $\mathrm{Cu}$ ore mining activities. $\mathrm{Ni}, \mathrm{Zn}, \mathrm{Cr}$ and $\mathrm{Cu}$ were the four dominant metals in the water and sediment samples of the Vale Sesii rivulet. The concentration 
of toxic metals in the Cu ores deposit areas depends upon the distance from the pollution source and scalar transport in rivulet flows and decreases along the flow direction. All studied metals had their highest concentration values in L3 and L4, sampling points located downstream of the discharge point of the Geamana tailing impoundment. The heavy metal in the surface water showed signs of contamination, HPI indicating high levels of heavy metal contamination for L3, L4, L5 and L6, in 2019 and for L3, in 2020. For the sediment samples, metal contamination was alarming, especially for $\mathrm{Cd}, \mathrm{Ni}$, $\mathrm{Pb}$ and $\mathrm{Cu}$, with $\mathrm{I}_{\text {geo }}$ highest value for $\mathrm{Cd}$ and $\mathrm{C}_{\mathrm{f}}$, for $\mathrm{Ni}$, respectively. The metal concentrations in sediments for the two years were quite similar, implying that the natural attenuation process was not adequate to remediate the sediments quality.

The results indicated that immediate and necessary treatment strategies and technologies to enhance surface water and sediment quality are required. Also, the obtained results will be an important step in proposing solutions for improving the water and sediment quality of Valea Sesii rivulet, as well as for establishing the influence of the polluted stream on the quality of its tributaries: Abrud and Aries River.

\section{EXPERIMENTAL SECTION}

\section{Study area and sampling procedures}

The Aries River is one of the most polluted surface waters in Romania, due to the intensive mining activities conducted in the area [40,41] Rosia Poieni is the largest unexploited porphyry copper deposit in Europe, representing $65 \%$ of the total copper reserve of Romania [42]. Annually, 5000 tons of copper are extracted from an open pit mine and the waters from the quarry perimeter are collected by the Aries River tributaries: Valea Strigoi, Valea Sesii, Valea Muscanilor and Valea Fantanilor [41, 43].

Six locations were selected for water and sediment sampling to evaluate the heavy metal contamination in Valea Sesii rivulet (Fig. 1). L1 and L2 were located upstream of the discharge point of the Rosia Poieni tailing impoundment (Geamana tailing pond-L3), situated at $\sim 3.85 \mathrm{~km}$ and $1.80 \mathrm{~km}$ for $L 1$ and for $L 2$, respectively, from $L 3$, while the rest of them were selected along the downstream watercourse at $\sim 2.00 \mathrm{~km}, 3.15 \mathrm{~km}$ and $4.30 \mathrm{~km}$, for L4, L5 and L6 respectively, from L3, in two sampling campaigns (November 2019 and November 2020). The water samples were collected in pre-cleaned polyethylene bottles that were rinsed three times with ultrapure water (Veolia Environment, France) before sample collection, and kept at $4^{\circ} \mathrm{C}$ until the analysis. Six samples were collected from the sediment top layer (about $0-20 \mathrm{~cm}$ ) using a plastic shovel and stored in polyethylene bags [44, 45]. 
ANA MOLDOVAN, ANAMARIA IULIA TÖRÖK, OANA CADAR, MARIUS ROMAN, CECILIA ROMAN, VALER MICLE

\section{Analysis of heavy metals}

The sediment samples were dried at $60{ }^{\circ} \mathrm{C}$ until constant weight, powdered by an agate mortar and passed through a $200 \mu \mathrm{m}$ mesh sieve. The fractions $<200 \mu \mathrm{m}$ were stored in polyethylene bags at room temperature until the analysis.

Samples were digested using Speedwave XPERT (Berghof, Germany) microwave digestion system according to the method described by Miclean et al. [46] with $\mathrm{HNO}_{3} 65 \%$ in the case of water samples and an acid mixture of $\mathrm{HNO}_{3} 65 \%$ and $\mathrm{HCl} 37 \%$ with a ratio of $1: 3(\mathrm{v} / \mathrm{v})$ in the case of sediment samples, respectively. The digested samples were quantitatively transferred to volumetric flasks and diluted to the mark with ultrapure water. The concentrations of metals ( $\mathrm{As}, \mathrm{Cd}, \mathrm{Cr}, \mathrm{Cu}, \mathrm{Pb}, \mathrm{Ni}$ and $\mathrm{Zn}$ ) in the surface water and sediments were determined using an ELAN DRC II inductively coupled mass spectrometer (Perkin Elmer, Waltham, Massachusetts, US).

Quality assurance and quality control were strictly implemented following the USEPA guidelines to ensure the accuracy of the analysis, using calibration standards, duplicate samples and procedural blank measurements [44]. The accuracy of the metal determination from water was checked by analysing $1643 \mathrm{f}$ NIST freshwater certified reference material (National Institute of Standards and Technology, Canada), and from sediments was checked by ERM-CC141 Loam soil certified reference material. Mean recoveries for the determination of metals in CRMs ranged between $94 \%$ and $105 \%$, in the case of water and between 88 and $108 \%$ in the case of sediments, respectively. The calibrations ranges and limits of detections are presented in Table 2.

Table 2. The metal determination calibration parameters

\begin{tabular}{|c|c|c|c|}
\hline & & Water & Sediment \\
\hline & Range of calibration & LOD & \\
\hline & & {$[\mu g / L]$} & {$[\mathrm{mg} / \mathrm{kg}]$} \\
\hline As & \multirow{7}{*}{$1-100 \mu \mathrm{g} / \mathrm{L}$} & 0.40 & 0.013 \\
\hline Cd & & 0.36 & 0.012 \\
\hline $\mathrm{Cr}$ & & 0.13 & 0.004 \\
\hline $\mathrm{Cu}$ & & 0.23 & 0.008 \\
\hline $\mathbf{P b}$ & & 0.37 & 0.012 \\
\hline $\mathbf{N i}$ & & 0.36 & 0.012 \\
\hline$Z \mathbf{n}$ & & 0.55 & 0.018 \\
\hline
\end{tabular}

\section{Heavy metal contamination assessments}

A combination of individual methods was employed to have a complete assessment of heavy metals contamination trends. Heavy metal pollution index HPI and heavy metal evaluation index HEI were used to 
assess the surface water contamination, while contamination factor $\mathrm{C}_{\mathrm{f}}$ and geo-accumulation index $I_{\text {geo }}$ were used for the sediment quality assessment.

$\mathrm{HPI}$ is a rating model that provides the composite influence of individual heavy metals on the overall water quality. The HPI model $[47,48]$ is given in Eq. (1) and (2):

$$
\begin{aligned}
& H P I=\frac{\sum_{i=1}^{n} Q_{i} W_{i}}{W_{i}} \\
& Q_{i}=\sum_{i=1}^{n} \frac{\left|C_{i}-I_{i}\right|}{M A C-I_{i}}
\end{aligned}
$$

where: $Q_{i}$ is the sub-index of $i^{\text {th }}$ parameter, $W_{i}$ is the unit weightage of the $i^{\text {th }}$ parameter and $n$ is the number of parameters considered. $C_{i}, l_{i}$ and MAC are the concentration of the $i^{\text {th }}$ parameter monitored, the ideal and quality standards concentration of the parameters established for the $\mathrm{V}$ class of surface water quality by Minister's Order 161/2006/OD and Directive 2008/32/CE [29, 30].

Regarding the level of pollution with heavy metals, HPI classifies the water bodies contamination levels in two categories: heavy metals low pollution level $(\mathrm{HPI}<100)$ and high level of pollution $(\mathrm{HPI}>100)$. A HPI value greater than 100 indicates that the water is unsuitable for consumption [47].

$\mathrm{HEI}$ provides an insight of the overall quality of groundwater with respect to heavy metals and is computed by Eq. $(3)[49,50]$.

$$
H E I=\sum_{i=1}^{n} \frac{C_{i}}{M A C}
$$

where $C_{i}$ is the determined concentration of the $\mathrm{i}^{\text {th }}$ parameter and MAC represents the quality standards concentration of the parameters established for the V class of surface water quality by Minister's Order 161/2006/OD and Directive 2008/32/CE [29, 30]. Classifications of water pollution degree based upon $\mathrm{HEl}$ are as follows: $<10$ low degree of pollution, $10-20$, medium degree and $>20$, high degree of pollution.

To identify the contributions of the metals to sediment pollution, contamination index $\mathrm{C}_{\mathrm{d}}$ (Eqs. 4-5) and geo-accumulation index $\mathrm{I}_{\text {geo }}$ (Eqs. 6) were assessed.

$$
\begin{aligned}
& C_{f}=\frac{C_{A i}}{C_{N i}}-1 \\
& C_{d}=\sum_{i=1}^{n}\left(c_{f}\right)
\end{aligned}
$$


where, $C_{A i}$ is the value of the concentration of $\mathrm{i}^{\text {th }}$ metal ions in the analyte and $C_{N i}$ represents the maximum allowable concentration (MAC) of the elements, according to the national legislation [24]. $C_{f}$ and $C_{d}$ results higher than 1.0 indicates a powerful contamination with metals [51]. The values of this index are: low contamination $\left(C_{f} \leq 1, L C\right)$; moderate contamination $\left(1 \leq \mathrm{C}_{\mathrm{f}} \leq 3, \mathrm{MC}\right)$; considerable contamination $\left(3 \leq \mathrm{C}_{\mathrm{f}} \leq 6, \mathrm{CC}\right)$; very high contamination $\left(\mathrm{C}_{f}>6, V H C\right)$, according to Arienzo [52].

$$
I_{\text {geo }}=\log _{2}\left(\frac{C_{m}}{1.5 * B_{m}}\right)
$$

where: $C_{m}$ is the heavy metal measured concentration in sediment; $B_{m}$ is the concentration of heavy metals in average shale values [34, 35]. Samples may be classified as practically uncontaminated ( $I_{\text {geo }} \leq 0$, Class 0 ), uncontaminated to moderately contaminated $\left(0 \leq I_{\text {geo }} \leq 1\right.$, Class 1$)$, moderately contaminated $\left(1 \leq I_{\text {geo }} \leq 2\right.$, Class 2$)$, moderate to heavily contaminated $\left(2 \leq I_{\text {geo }} \leq 3\right.$, Class 3$)$, heavily contaminated ( $3 \leq I_{\text {geo }} \leq 4$, Class 4$)$, heavily to extremely contaminated $\left(4 \leq I_{\text {geo }} \leq 5\right.$, Class 5$)$, and extremely contaminated (I $I_{\text {geo }} \geq 5$, Class 6$)$ [52].

\section{ACKNOWLEDGMENTS}

This paper was supported by the Project "Entrepreneurial competences and excellence research in doctoral and postdoctoral programs - ANTREDOC", project co-funded by the European Social Fund, Project CEO-TERRA, project co-financed by the European Fund for Regional Development, through the Competitiveness Operational Program 2014-2020, project no. POC-A.1A.1.1.1- F- 2015-152/2016 and the Core Program, under the support of ANCS, project no. PN 19-18.01.01 (contract no. 18N/08.02.2019). The funder had no role in the design of the study; in the collection, analysis and interpretation of data; in the writing of the manuscript, and in the decision to submit the article for publication.

\section{REFERENCES}

1. S. Dash, S.S. Borah; A. Kalamdhad; Ecol. Indic., 2019, 106.

2. M.S. Bhuyan, M.A. Bakar, A. Akhtar, M.B. Hossain, M.M. Ali; M.S. Islam; Environ. Nanotechnol. Monit. Manag., 2017, 8, 273-279.

3. M.S. Islam, M.K. Ahmed, M. Raknuzzaman, M. Habibullah -Al- Mamun; M.K. Islam; Ecol. Indic., 2015, 48, 282-291.

4. M.A. Islam, B. Das, S.B. Quraishi, R. Khan, K. Naher, S.M. Hossain, S. Karmaker, S.A. Latif; M.B. Hossen; Mar. Pollut. Bull., 2020, 160, 111649.

5. A. Cendrero, L.M. Forte, J. Remondo; J.A. Cuesta-Albertos; Earth's Future, 2020, 8.

6. W. Salomons U. Förstner, Metals in the Hydrocycle. 1984. 
7. M.-A. Hoaghia, A. Moldovan, E. Kovacs, I.C. Mirea, M. Kenesz, T. Brad, O. Cadar, V. Micle, E.A. Levei; O.T. Moldovan; Water, 2021, 13.

8. Y. Zeng, C. Bi, J. Jia, L. Deng; Z. Chen; Ecol. Indic., 2020, 116.

9. V. Kumar, R.D. Parihar, A. Sharma, P. Bakshi, G.P. Singh Sidhu, A.S. Bali, I. Karaouzas, R. Bhardwaj, A.K. Thukral, Y. Gyasi-Agyei; J. Rodrigo-Comino; Chemosphere, 2019, 236, 124364.

10. O.C. Ihunwo, A.N. Dibofori-Orji, C. Olowu; M.U. Ibezim-Ezeani; Mar. Pollut. Bull., 2020, 154, 111042.

11. N.U. Benson, A.E. Adedapo, O.H. Fred-Ahmadu, A.B. Williams, E.D. Udosen, O.O. Ayejuyo; A.A. Olajire; Reg. Stud. Mar. Sci., 2018, 18, 44-56.

12. M. Saleem, J. Iqbal; M.H. Shah; Environ. Nanotechnol. Monit. Manag., 2015, 4, 27-36.

13. Y. Zhao, M. Xu, Q. Liu, Z. Wang, L. Zhao; Y. Chen; Mar. Pollut. Bull., 2018, 137, 601-609.

14. P. Weber, E.R. Behr, C.D.L. Knorr, D.S. Vendruscolo, E.M.M. Flores, V.L. Dressler; B. Baldisserotto; Microchem. J., 2013, 106, 61-66.

15. D. Qiao, G. Wang, X. Li, S. Wang; Y. Zhao; Chemosphere, 2020, 248, 125988.

16. F. Botsou, A.P. Karageorgis, E. Dassenakis; M. Scoullos; Mar. Pollut. Bull., 2011, 62, 547-63.

17. M.E. Goher, A.M. Hassan, I.A. Abdel-Moniem, A.H. Fahmy; S.M. El-sayed; Egypt. J. Aquat. Res., 2014, 40, 225-233.

18. V. Kumar, A. Sharma, R. Kumar, R. Bhardwaj, A. Kumar Thukral; J. RodrigoComino; Human. Ecol. Risk. Assess., 2018, 26, 1-16.

19. M. Li, Q. Zhang, X. Sun, K. Karki, C. Zeng, A. Pandey, B. Rawat; F. Zhang; Chemosphere, 2020, 244, 125410.

20. G. Zhao, S. Ye, H. Yuan, X. Ding, J. Wang; E.A. Laws; Mar. Pollut. Bull., 2018, 136, 300-308.

21. I. Karaouzas, N. Kapetanaki, A. Mentzafou, T.D. Kanellopoulos; N. Skoulikidis; Chemosphere, 2021, 263, 128192.

22. A.M. Hussein, D. Neama Jabbar; A.R. Ali; Alex. Eng. J., 2020, 59, 5197-5206.

23. M. Sima, B. Dold, L. Frei, M. Senila, D. Balteanu; J. Zobrist; J Hazard Mater, 2011, 189, 624-39.

24. V. Constantin, L. Ştefănescu; C.-M. Kantor; Environ. Sci. Policy, 2015, 52, 129-139.

25. A. Ozunu, L. Stefanescu, C. Costan, M. Miclean, C. Modoi; S.-N. Vlad; Environl. Eng. Manag. J., 2009, 8, 809-815.

26. B. Dold; Minerals, 2014, 4, 621-641.

27. E. Levei, M. Senila, M. Miclean, B. Abraham, C. Roman, L. Stefanescu; O.T. Moldovan; Environl. Eng. Manag. J., 2011, 10, 23-29.

28. A. Moldovan, M.A. Hoaghia, V. Băbălău-Fuss, M. Roman, G. Hognogi, V. Micle; Agric. Sci., 2020, 113.

29. Directive 2008/32/EC of the European Parliament and of the Council of 11 March 2008 amending Directive 2000/60/EC establishing a framework for Community action in the field of water policy, as regards the implementing powers conferred on the Commission. 
30. Ministerial Order no. $161 / 2006$ for the approval of the Norm regarding the classification of surface water quality in order to establish the ecological status of the water bodies. 2006.

31. M. Senila, E.A. Levei, L.R. Senila; M. Roman; J. Chem., 2015, 2015, 1-8.

32. L. Ning, Y. Liyuan, D. Jirui; P. Xugui; Procedia. Environ. Sci., 2011, 10, 914-917.

33. G. Schertzinger, N. Ruchter; B. Sures; Sci. Total. Environ., 2018, 616-617, 1199-1207.

34. K.K. Turekian K.H. Wedepohl; Geol. Soc. Am. Bull., 1961, 72.

35. N.A. Barbieri M, Sappa g.; Senses. Sci., 2015, 2, 94-97.

36. S. Lynch, L. Batty; P. Byrne; Minerals, 2014, 4, 52-73.

37. C.J. Gandy, J.W. Smith; A.P. Jarvis; Sci Total Environ, 2007, 373, 435-46.

38. L. Moreno I. Neretnieks; Hydrometallurgy, 2006, 83, 176-183.

39. W.M. Mayes, E. Gozzard, H.A. Potter; A.P. Jarvis; Environ Pollut, 2008, 151, 165-75.

40. E. Levei, M. Ponta, M. Senila, M. Miclean; T. Frentiu; J. Serbian. Chem. Soc., 2014, 79, 1019-1036.

41. E. Levei, T. Frentiu, M. Ponta, C. Tanaselia; G. Borodi; Chem. Cent. J., 2013, 7, 5.

42. E. Luca, Roman, C., Chintoanu, M., Luca, L., Puscas, A., Hoban, A.; Agricultura -Stiinta si practica, $20063-4,59-60$.

43. P. Rzymski, P. Klimaszyk, W. Marszelewski, D. Borowiak, M. Mleczek, K. Nowinski, B. Pius, P. Niedzielski; B. Poniedzialek; Environ. Sci. Pollut. Res. Int., 2017, 24, 21445-21458.

44. USEPA, Sediment Sampling. United States Environmental Protection Agency. 2014: Georgia, United States.

45. USEPA, Surface Water Sampling. United States Environmental Protection Agency. 2016: Georgia, United States.

46. M. Miclean, E.A. Levei, O. Cadar, M. Senila; I.S. Groza; Carpathian. J. Earth. Environ. Sci., 2013, 8, 93-100.

47. K. Wątor R. Zdechlik; Ecol. Indic., 2021, 121.

48. L. Qu, H. Huang, F. Xia, Y. Liu, R.A. Dahlgren, M. Zhang; K. Mei; Environ. Pollut., 2018, 237, 639-649.

49. M.A. Bhuiyan, M.A. Islam, S.B. Dampare, L. Parvez; S. Suzuki; J. Hazard. Mater., 2010, 179, 1065-77.

50. A.E. Edet O.E. Offiong; GeoJournal, 2002, 57, 295-304.

51. R. Ullah S. Muhammad; Environ. Technol. Innov., 2020, 19.

52. M. Arienzo, L. Ferrara, M. Toscanesi, A. Giarra, C. Donadio; M. Trifuoggi; Mar. Pollut. Bull., 2020, 155, 111149. 